\title{
O Corpo em Fuga e Si Mesmo
}

Norval Baitello Júnior

PUC-SP

In Memoriam Luís Otávio Burnier Pessoa de Mello

Quando em 1967, o psicólogo norte-americano Alexander Lowen publica The Betrayal of the Body (aprofundando veredas abertas por Wilhelm Reich, o qual, por sua vez, recebera em legado de ousadia e inovação de seu mestre Sigmund Freud) o mundo ocidental se confrangia e rejubilava com uma "nova" descoberta da entidade chamada 'corpo'. Muitos, ainda imbuídos por um tipo de crença na pureza original, acreditavam em um resgate puro e simples de algo dado pela natureza ou por Deus. Outros se perguntavam qual seria a natureza dessa entidade, seguramente mais poderosa que qualquer pressão advinda da história ou repressão advinda de normas culturais. O próprio Alexander Lowen diz:

"O corpo vivo possui uma vida própria intensa. Ele dispõe de uma mobilidade que não se submete ao controle do ego e que se manifesta na espontaneidade de seus gestos e na intensidade de sua expressão." (Lowen, 1983: 217)

Com âncoras lançadas na crença da espontaneidade gestual $e$ da expressividade intensa, o psicoterapeuta desenvolve um método de trabalho corporal, séries de exercícios e posturas, objetivando o resgate de um corpo perdido no decorrer de uma história de vida, ou no decorrer de processos civilizatórios. Resgatar a originalidade virtuosa, esta era a palavra de ordem. Parecia ter chegado ao fim a longa noite repressora que começara nos primórdios dos tempos míticos, com a expulsão de Adão e Eva. E o notável Festival de Woodstock sinalizava a reconquista ruidosa do Jardim do Éden, inaugurava uma nova e promissora era. E nenhum símbolo de rebeldia e protesto seria mais adequado que o corpo, novamente despido dos mantos da vergonha, da culpa e do pecado. 


\section{O corpo encerra em si a história?}

Novas abordagens, menos ou mais simplistas, menos ou mais complexas, se desenvolveram paralelamente e também nos anos e décadas seguintes. Algumas se motivaram na constatação de traços da história da espécie, atualizados na memória do indivíduo. Resíduos de vivências primordiais que ajudaram a construir a espécie em sua filogênese são descobertos pela pesquisa empírica.

O corpo encerra em si uma história muito mais profunda e abrangente do que aquela que nossa memória cerebral pode abranger. Suspeita-se da existência de um código de memória intermediário entre o código genético e os códigos culturais da memória social. Posturas, gestos comunicativos, comportamentos, enfim, são predisposições posteriores ao genoma e anteriores hábitos e a aprendizagem culturais; supõe-se então que façam parte ainda do corpo instâncias de registros não penas biológicos mas também históricos. Os estudos da etologia vieram embasar investigações e especulações as mais diversas, mas é inegável que trouxeram chão a inúmeras áreas de investigação, dentre elas as Ciências da Comunicação, para as quais os estudos e descobertas da Etologia (Humana) significam o resgate de uma arqueologia comunicativa do homem. Para esta arqueologia, a instância "corpo" é o início de toda comunicação humana. Estudos como os de Eibl-Eibesfeldt sobre os "rituais de vínculo" (cf. EiblEibesfeldt, 1983) ou então as encantadoras revelações sobre microgestos que, muito aquém dos limiares da percepção consciente, interferem poderosamente nos processos de interação humana. Movimentos faciais de frações de segundo, posturas, movimentos de olhos, pálpebras, sobrancelhas, ângulos da boca constituem um importante terreno intermediário entre o biológico e o cultural. As "predisposições" comunicativas, registradas nas instâncias do biológico, tornam-se linguagem, gestos, atitudes, movimentos, bastando, para isso, que sejam estimuladas social e culturalmente; reduz-se, aí, o tempo de aprendizagem dos códigos da comunicação humana a um período muito pequeno e a um esforço ainda menor. Por serem registros de uma história da espécie nos largos tempos da evolução filogenética, as predisposições oferecem um conceito de corpo muito além da "physis", um corpus de informações virtuais, em potência, que será estimulado socialmente e assim poderá tornar-se o indivíduo social e cultural que todos somos. 


\section{Tecer o corpo, mídia primeira}

Compreender que o corpo não é apenas um sistema biológico, mas também social e cultural, esta tem sido a preocupação atual de áreas novas e velhas do saber que se dedicam a investigar os fluxos informacionais intersistêmicos. Compreender em que consiste o complexo que denominamos 'corpo' requer a derrubada de muros e fronteiras estabelecidas. Uma vez que é entidade cultural, portanto história, resultado de um percurso, sua essência não está na permanência, mas na mudança. Uma vez que é entidade biológica, sua natureza não é aleatoriamente mutável, mas impõe limites de flexibilidade apenas moderada. Uma vez que é meio de comunicação, sua essência consiste em produzir, veicular e armazenar informações, gerando textos dentro dos quais se projetam, inclusive a si próprios. Assim, corpo é vida biológica, é texto (tecido de cultura), é gerador de códigos comunicativos e ele próprio linguagem formadora de redes sociais e culturais nas quais se insere.

Harry Pross o denomina "mídia primária' (cf. Pross, 1972), aquela que é a base de toda a mídia restante (acústica, visual e eletrônica). Sem a mídia primária e sua complexidade comunicativa, não se desenvolve o quadro de diversidade midiática que caracteriza nossa contemporaneidade.

Cabe, assim, compreender o "texto" corpo, mídia primária, como intersecção de fluxos de diversa e múltipla natureza. A entidade "corpo biológico" fornece um substrato importante, mas não exclusivo; "corpo social" é uma expansão do corpo biológico, gerado e gerador dos vínculos que mantém viva uma sociedade; o "corpo cultural", aquele que a história do imaginário humano idealiza e gera, texto cultural por excelência.

\section{O corpo em fuga}

A convicção de que o corpo é linguagem, resultante de confluência de códigos complexos em múltiplos níveis fez do trabalho de formação do ator, desenvolvido por Luís Otávio Burnier no LUME, a mais completa concepção de corpo aplicada em processo de preparação do ator: não ignorando a dimensão biológica e fisiológica, 
mas, ao mesmo tempo, não cedendo diante dela; não se esquecendo da complexa história das falas sociais do corpo e, paralelamente, expandindo-as; dialogando com a mais expressiva codificação cultural e sua história, mas não reduzindo o homem a suas crenças e seus ideários, remetidos de volta à sua realidade primeira, à sua mídia primária. Olhados com a visão tipologizadora, poderíamos dizer que se trata de três corpos diferentes que dialogam entre si, em um jogo de combinatória caleidoscópica. O primeiro, o biológico, o segundo, o social, o terceiro, o cultural. Mas não basta separar especificidades. $O$ importante é estar sempre fugindo delas, fugindo de si mesmo, em busca do outro corpo.

Esta foi sempre a minha sensação e posterior confirmação ao ver os trabalhos preparatórios e teatrais de Luís Otávio Burnier. Agora, recordando nossas longas conversas de orientação de tese, repassando os meus momentos de encantamento diante de seu trabalho teatral, revivendo e rememorando a generosidade artística, intelectual e humana, vem-me à mente a seguinte cena fabular.

O corpo um, cansado e descontente de ser só corpo, fugiu de si mesmo em busca dos outros horizontes, pretensamente alcançados por dois e três. O corpo dois, igualmente infeliz de sua identidade de linguagem, partiu em busca das outras amplitudes, próprias do um e do três. O corpo três, ansioso por não se ater às suas amarras oníricas e imaginárias, abandonou-se e rumou em direção a outras qualidades de seus iguais, em busca de eternidades.

Natureza, técnica e arte em diálogo agônico de titãs arquitetaram a vertiginosa dinâmica do corpo em fuga de si mesmo.

\section{Referências Bibliográficas}

Bristina, Ivan (1989). Semiotic der Kultur (Semiótica da Cultura). Tübingen: Stauffenburg, 1968.

Eibl-Elbesbeldt. Irenäus (1983) El hombre preprogramado. Madrid: Alianza, 1983.

Lowen, Alexander (1983) Der Verrat in Körper (A Traição do Corpo). Reinberck: Rowohlt, 1983.

Pross, Harry (1972) Medienforschung (Pesquisa da Mídia) Darmstadt: Carl Habel, 1972. 